\title{
The birth prevalence of lysosomal storage disorders in the Czech Republic: comparison with data in different populations
}

\author{
Helena Poupětová • Jana Ledvinová • Linda Berná • \\ Lenka Dvořáková • Viktor Kožich • Milan Elleder
}

Received: 28 January 2010 /Revised: 25 March 2010 / Accepted: 26 March 2010 /Published online: 20 May 2010

(C) The Author(s) 2010. This article is published with open access at Springerlink.com

\begin{abstract}
The aim of this retrospective study was to determine the prevalence of lysosomal storage disorders (LSDs) in the Czech Republic. The data on cases diagnosed between 1975 and 2008 were collected and analyzed. The overall prevalence of LSDs in the Czech population $(12.25$ per 100,000$)$ is comparable to that reported for the countries with wellestablished and advanced diagnostics of LSDs such as the Netherlands (14 per 100,000), Australia (12.9 per 100,000) and Italy (12.1 per 100,000). Relatively higher prevalence of LSDs was reported in the north of Portugal (25 per 100,000). Thirty-four different LSDs were diagnosed in a total of 478 individuals. Gaucher disease was the most frequent LSD with a birth prevalence of 1.13 per 100,000 births. The most frequent LSD groups were lipidoses, mucopolysaccharidoses, and neuronal ceroid lipofuscinoses, with combined prevalences of 5.0, 3.72, and 2.29 per 100,000 live births, respectively. Glycoproteinoses ( 0.57 per 100,000 live births), glycogenosis type II (0.37), and mucolipidoses (0.31) rarely occur in the Czech population, and a range of other LSDs have not been detected at all over the past three decades. Knowledge of the birth prevalence and carrier frequency of particular disorders is important in genetic counselling for calculation of the risk for the disorder in the other members of affected families. Earlier diagnosis of these disorders will permit timely intervention and
\end{abstract}

Communicated by: Ed Wraith

Competing interest: None declared.

H. Poupětová · J. Ledvinová • L. Berná • L. Dvořáková •

V. Kožich $\cdot$ M. Elleder $(\bowtie)$

Institute of Inherited Metabolic Disorders,

First Faculty of Medicine, Charles University in Prague

and General University Hospital in Prague,

Ke Karlovu 2,

12808 Prague 2, Czech Republic

e-mail: melleder@cesnet.cz may also result in lowering of the number of newborns with LSDs.

\section{Introduction}

Following the discovery of the lysosome by the Nobel Prize winner Christian de Duve in 1955 (De Duve et al. 1955), research into the biochemistry, molecular biology and pathology of the lysosomal system unravelled many of its functions.

Nowadays, genetic lysosomal storage disorders (LSDs) represent a group of about 50 disorders (Scriver et al. 2001; Staretz-Chacham et al. 2009). All of them are characterized by intralysosomal accumulation of compound(s), e.g., enzyme substrates or products, mishandled bioconjugates, or segregated cytoplasmic components, in a variety of cell types and tissues. Most LSDs result from a deficient enzyme activity caused by a mutation in the gene encoding either the relevant enzyme, protecting protein, protein activators, or the endoplasmic reticulum-Golgi enzyme systems responsible for proper protein posttranslational modification. However, some are caused by dysfunction of the lysosomal system itself due to mutations in genes encoding lysosomal membrane components or components closely associated with the lysosomal system (Saftig 2005; Jalanko and Braulke 2009). The number of lysosomal enzymes and non-catalytic proteins reported in the literature has steadily increased and, therefore, more defects in the lysosomal system are expected to be discovered. The progress in the research into LIMP-2 deficiency serves as a recent example (Balreira et al. 2008; Berkovic et al. 2008).

Overall frequencies of occurrence of LSDs have been reported for several countries (Meikle et al. 1999; Poorthuis et al. 1999; Applegarth et al. 2000; Dionisi-Vici et al. 2002; 
Fig. 1 Relative rate of lysosomal storage disorders in the Czech Republic. MPS Mucopolysaccharidosis, NCL neuronal ceroidlipofuscinosis, GSD II glycogenosis type II, $M L$ mucolipidosis, $G P$ glycoproteinosis, $N P A / B / C$ Niemann-Pick $\mathrm{A} / \mathrm{B} / \mathrm{C}, M L D$ metachromatic leukodystrophy, CESD cholesterol ester storage disease, MSD multiple sulphatase deficiency, GM1 GM1 gangliosidosis, GM2 GM2 gangliosidosis (Tay-Sachs and Sandhoff diseases), $\beta$-Man $\beta$-mannosidosis, $\alpha$-Man $\alpha$-mannosidosis, ISSD infantile sialic acid storage disease
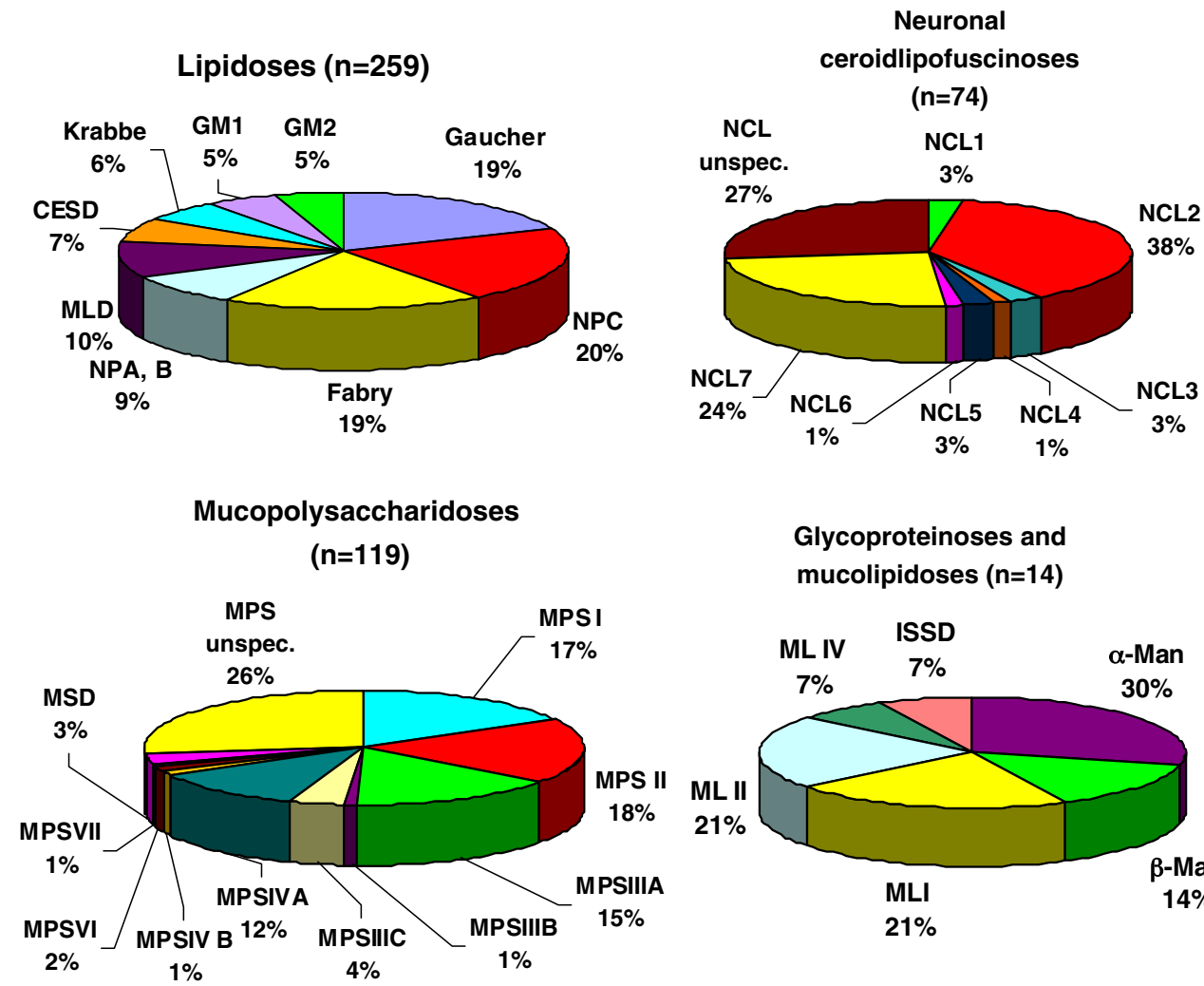

\section{Glycoproteinoses and} mucolipidoses $(n=14)$

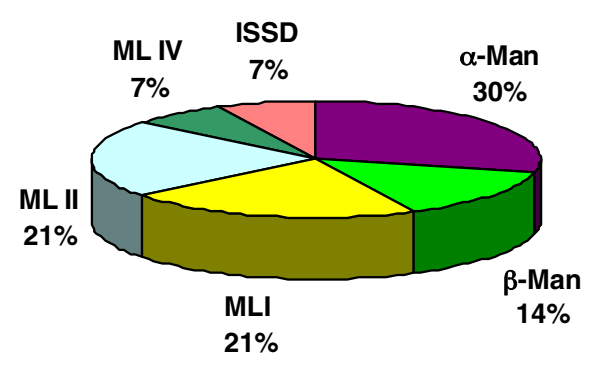

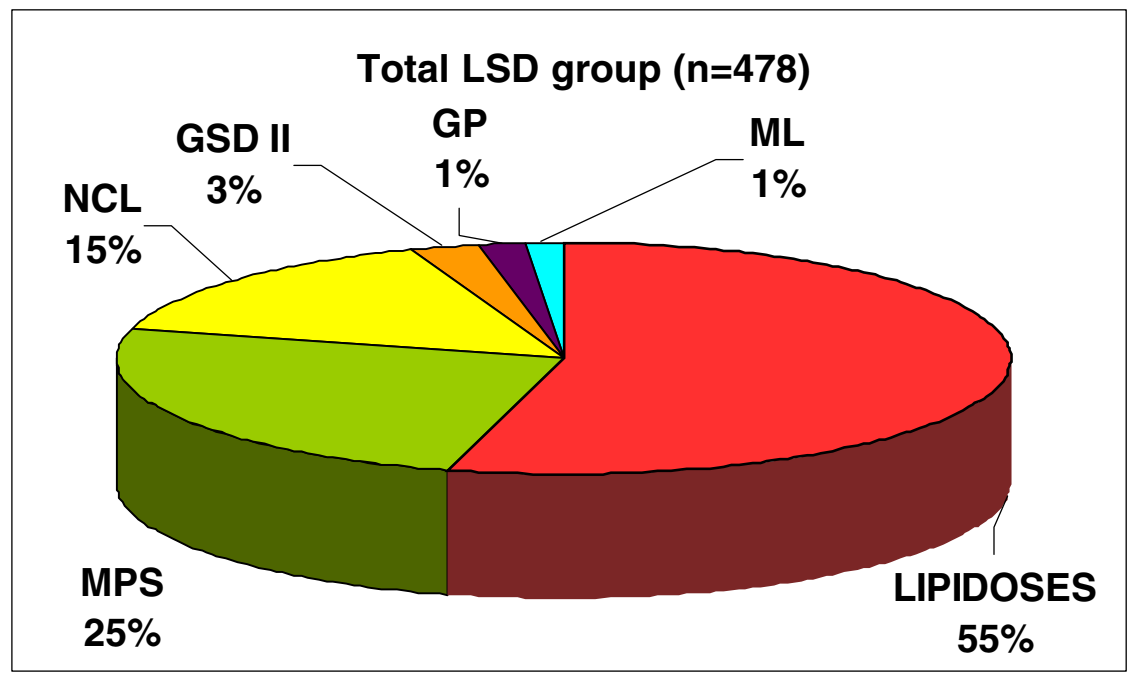

Pinto et al. 2004), while other reports focused on LSD groups (e.g., mucopolysaccharidoses, (MPS): Nelson et al. 2003; Baehner et al. 2005; Malm et al. 2008; lipidoses: Ozkara and Topcu 2004; neuronal ceroid lipofuscinoses, NCL: Claussen et al. 1992), or on particular LSDs (e.g., MPS I: Moore et al. 2008; metachromatic leukodystrophy and Krabbe disease: Heim et al. 1997). The frequency of LSDs as a group varies among populations from 7.6 to 25 per 100,000 (Meikle et al. 1999; Poorthuis et al. 1999; Applegarth et al. 2000; Dionisi-Vici et al. 2002; Pinto et al. 2004).

The aim of this study was to calculate the birth prevalence and carrier frequencies of LSDs in the Czech Republic population, and to compare our results with reported epidemiologic data from other populations.

\section{Patients and methods}

We analyzed data from individuals who had been diagnosed with a LSD at the Institute of Inherited Metabolic Disorders in Prague between 1975 and 2008. Our Institute is the only laboratory providing diagnostic testing for LSDs, including prenatal testing, in the Czech Republic. The patients had been referred to, or their blood samples had been sent to, the Institute 


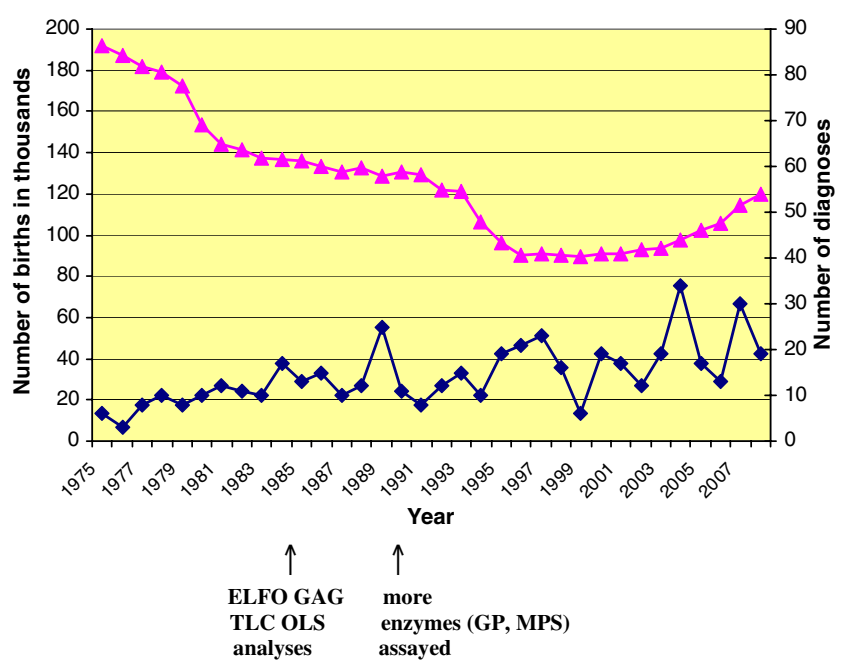

Fig. 2 Number of live births ( $\boldsymbol{\Delta}$ ) and number of LSD diagnoses $(\bullet)$ in the Czech population from 1975 to 2008. In 1985, electrophoretic analysis of glycosaminoglycans (ELFO GAG) and thin layer chromatography of oligosaccharides (TLC OLS) in urine were introduced. From 1990 onwards, enzyme assays for mucopolysaccharidoses and glycoproteinoses were gradually introduced. Nowadays, laboratory diagnostic methods for 45 LSDs are available (enzyme and DNA analyses, loading assays)

by Departments of Paediatrics, Neurology, Haematology, Cardiology, Nephrology, Dermatology, Gastroenterology, Ophthalmology, Pathology, and Clinical Genetics from hospitals all over the country.
The initial diagnosis of most LSDs was based on demonstration of accumulated substrates (e.g., sphingolipids, oligosaccharides, or glycosaminoglycans) in tissues and/or body fluids using chromatographic or electrophoretic methods, or on histological proof of storage. The definite diagnosis was made by demonstrating the deficiency of the relevant enzyme and/or presence of pathogenic mutation, and/or by detection of undegraded substrate by loading tests in cell cultures. Mucolipidosis II was confirmed by detecting elevated activities of multiple lysosomal enzymes in serum and by molecular analysis. Patients with unspecified types of MPS or NCL, who had died before the availability of confirmatory tests, were also included in the birth prevalence calculation. Their diagnosis was based on biochemical analyses of storage compound, evaluation of clinical data, and histochemical and/or ultrastructural examinations of samples obtained at biopsy or autopsy.

For the calculation of the prevalence, we used the method published by Poorthuis et al. (1999). The prevalence was calculated as the total number of patients diagnosed with a particular LSD, divided by the total number of live births in the same period, as was the birth period of the diagnosed cases (i.e., the birth period is the interval between the year of the birth of the oldest patient and the year of the birth of the youngest patient). Birth prevalence was expressed as the number of patients per 100,000 live births. The total number of live births in particular years was calculated using birth rates taken from

Table 1 Lipidoses: comparison of data in different populations

\begin{tabular}{|c|c|c|c|c|c|c|c|c|}
\hline \multirow[t]{2}{*}{ Disease } & \multicolumn{4}{|l|}{ Czech Republic } & \multicolumn{4}{|c|}{ Other countries } \\
\hline & $\begin{array}{l}\text { No. of patients } \\
1975-2008^{\mathrm{a}}\end{array}$ & $\begin{array}{l}\text { Prevalence } \\
\text { per } 100,000^{\mathrm{b}}\end{array}$ & $\begin{array}{l}\text { Poisson } 95 \% \\
\text { confidence interval }\end{array}$ & $\begin{array}{l}\text { Carrier } \\
\text { frequency }^{\mathrm{c}} \times 10^{3}\end{array}$ & $\begin{array}{l}\text { NL } \\
\text { Preval }\end{array}$ & $\begin{array}{l}\text { Portugal } \\
\text { nce per } 10\end{array}$ & $\begin{array}{l}\text { Australia } \\
, 000 \text { live birt }\end{array}$ & $\begin{array}{l}\text { Turkey } \\
\text { ths }\end{array}$ \\
\hline Gaucher (all types) & 49 & 1.13 & $0.61-1.95$ & 6.71 & 1.16 & 1.35 & 1.75 & 0.45 \\
\hline Niemann-Pick A/B & 23 & 0.33 & $0.16-0.61$ & 3.65 & 0.53 & 0.6 & 0.4 & \\
\hline Niemann-Pick C & 54 & 0.91 & $0.67-1.21$ & 6.02 & 0.35 & 2.2 & 0.47 & \\
\hline Fabry male & 49 & $0.52(1.0)^{\mathrm{d}}$ & $0.38-0.69$ & 0.01 & 0.21 & 0.12 & 0.86 & 0.015 \\
\hline Fabry female & 78 & 0.77 & $0.60-0.98$ & & & & & \\
\hline Krabbe & 15 & 0.40 & $0.21-0.68$ & 4.0 & 1.35 & 1.21 & 0.71 & 1 \\
\hline MLD (all types) & 25 & 0.69 & $0.29-1.38$ & 5.26 & 1.42 & 1.85 & 1.09 & 1.43 \\
\hline CESD, Wolman & 18 & 0.27 & $0.15-0.45$ & 3.31 & & & 0.19 & \\
\hline GM1 gangliosidosis & 13 & 0.26 & $0.14-0.46$ & 3.25 & 0.41 & 0.62 & 0.26 & 0.54 \\
\hline GM2 Tay-Sachs & 10 & 0.30 & $0.14-0.55$ & 3.45 & 0.41 & 3.13 & 0.5 & 0.23 \\
\hline GM2 Sandhoff & 3 & 0.19 & $0.04-0.55$ & 2.74 & 0.34 & 1.49 & 0.26 & 0.95 \\
\hline Lipidoses all types & $259^{\mathrm{e}} / 337^{\mathrm{f}}$ & $5.0^{\mathrm{e}} / 5.77^{\mathrm{f}}$ & $2.79(3.39)-8.53(9.51)$ & & 6.2 & 12.6 & 6.6 & 4.6 \\
\hline
\end{tabular}

$N L$ Netherlands, $M L D$ metachromatic leukodystrophy, CESD cholesteryl ester storage disease

${ }^{\text {a }}$ Total number of patients diagnosed between 1975 and 2008

${ }^{\mathrm{b}}$ Data for prevalence calculations are in Table 4

${ }^{\mathrm{c}}$ Carrier per 1 live birth

${ }^{\mathrm{d}}$ Male live births only

${ }^{\mathrm{e}}$ Fabry females not included

${ }^{\mathrm{f}}$ Fabry females included 
Table 2 Mucopolysaccharidoses: comparison of data in different populations

\begin{tabular}{|c|c|c|c|c|c|c|c|c|}
\hline \multirow{3}{*}{$\begin{array}{l}\text { Disease } \\
\text { MPS I }\end{array}$} & \multicolumn{4}{|l|}{ Czech Republic } & \multicolumn{4}{|c|}{ Other countries } \\
\hline & \multirow{2}{*}{$\begin{array}{l}\text { No. of patients } \\
1975-2008^{\mathrm{a}}\end{array}$} & \multirow{2}{*}{$\begin{array}{l}\begin{array}{l}\text { Prevalence } \\
\text { per } 100,000^{\mathrm{b}}\end{array} \\
0.72\end{array}$} & \multirow{2}{*}{$\begin{array}{l}\begin{array}{l}\text { Poisson } 95 \% \\
\text { confidence interval }\end{array} \\
0.44-1.11\end{array}$} & \multirow{2}{*}{$\begin{array}{l}\begin{array}{l}\text { Carrier } \\
\text { frequency }^{\mathrm{c}} \times 10^{3}\end{array} \\
5.38\end{array}$} & \multicolumn{4}{|c|}{ Prevalence per 100,000 live births } \\
\hline & & & & & 1.19 & 1.33 & 1.14 & 0.69 \\
\hline MPS II & 22 & $0.43(0.83)^{\mathrm{d}}$ & $0.26-0.65$ & 0.0085 & 0.67 & 1.09 & 0.74 & 0.64 \\
\hline MPS III A & 18 & 0.47 & $0.27-0.75$ & 4.31 & 1.16 & 0 & 0.88 & \\
\hline MPS III B & 1 & 0.02 & $0.0-0.13$ & 0.97 & 0.42 & 0.72 & 0.47 & \\
\hline MPS III C & 5 & 0.42 & $0.14-0.99$ & 4.12 & 0.21 & 0.12 & 0.07 & \\
\hline MPS III D & 0 & 0 & & & 0.1 & & 0.10 & \\
\hline MPS III (all types) & 24 & 0.91 & $0.41-1.87$ & & 1.89 & 0.84 & 1.42 & 1.57 \\
\hline MPS IV A & 14 & 0.71 & $0.38-1.22$ & 5.35 & 0.22 & 0.6 & 0.59 & \\
\hline MPS IV B & 1 & 0.02 & $0.0-0.13$ & 0.97 & 0.14 & 0 & 0 & \\
\hline MPS IV $(A+B)$ & 15 & 0.73 & $0.38-1.35$ & & & & & 0.38 \\
\hline MPS VI & 2 & 0.05 & $0.01-0.18$ & 1.40 & 0.15 & 0.42 & 0.43 & 0.23 \\
\hline MPS VII & 1 & 0.02 & $0.0-0.13$ & 0.97 & 0.24 & 0 & 0.05 & \\
\hline MPS unspecified ${ }^{\mathrm{e}}$ & 32 & 0.60 & $0.39-0.87$ & & & & & \\
\hline MSD & 3 & 0.26 & $0.05-0.77$ & 3.24 & 0.05 & 0.48 & 0.07 & \\
\hline MPS all types & 119 & 3.72 & $1.94-6.93$ & & 4.5 & 4.8 & 4.44 & 3.53 \\
\hline
\end{tabular}

NL Netherlands, MPS mucopolysaccharidosis, MSD multiple sulphatase deficiency

${ }^{\mathrm{a}}$ Total number of patients diagnosed between 1975 and 2008

${ }^{\mathrm{b}}$ Data for prevalence calculations are in Table 5

${ }^{\mathrm{c}}$ Carrier per 1 live birth

${ }^{\mathrm{d}}$ Male live births only

${ }^{\mathrm{e}}$ Unspecified cases of MPS were diagnosed on the basis of analysis of glycosaminoglycan excreted in urine combined with the evaluation of clinical data. No material was available for enzyme and DNA analysis

the Czech Statistical Office web page. To avoid underestimation, some patients were not included into the prevalence calculation (e.g., patients born before 1945 were excluded). If there was only one patient diagnosed with the disease, the prevalence was calculated using the number of live births (i.e., 4,261,897) in the examined period (i.e., between 1975 and 2008), as used previously by Pinto et al. (2004). Familial cases and 11 affected fetuses [Fabry disease (1), Niemann-Pick disease type C (1), MPS I (3), MPS III A (3) and MPS IV A (3)] were also included in the calculation of birth prevalence.

For some specific LSDs, the patient group consisted of subgroups with distinct clinical phenotypes (e.g., MLD, Gaucher disease). Using the method mentioned above, we calculated the prevalence of the subgroups separately, and the overall prevalence of the specific LSD was estimated as a sum of the prevalences in the subgroups (Poorthuis et al. 1999).

Calculation of the frequency of Fabry disease was done using two approaches, i.e., excluding and including female heterozygotes. Exclusion of heterozygotes $(n=78)$ enabled us to compare the prevalence to other reported malespecific prevalence data (Meikle et al. 1999; Poorthuis et al. 1999; Ozkara and Topcu 2004; Pinto et al. 2004). Fabry heterozygotes, who can be as severely affected as male patients, are nowadays classified as "patients" instead of "carriers of the defective gene" (Dobrovolny et al. 2005; Wang et al. 2007; Gibas et al. 2008). Therefore, we also calculated the prevalence including Fabry females.

Confidence intervals (95\%) for the birth prevalences were estimated from the Poisson distribution using SISA (Simple Interactive Statistical Analysis) software (Uitenbroek 1997). Carrier frequency was calculated using the Hardy-Weinberg equation (Strachan and Read 2004).

\section{Results}

In the past three decades, a total of 478 patients have been diagnosed with one of 34 specific types of LSDs in the Czech Republic (Fig. 1). The number of diagnosed patients gradually increased during the study period, from less than 10 cases per year in the 1970s to 20-30 new cases diagnosed annually in recent years (Fig. 2). More than half of all LSD patients had a lipidosis, about one-quarter a mucopolysaccharidosis, and the remaining quarter suffered from NCL, GSD II, mucolipidoses, or glycoproteinoses (Fig. 1). The combined birth prevalence for all LSDs is 12.25 (95\% CI 6.25-24.1) per 100,000 live 
Table 3 Glycoproteinoses, mucolipidoses, glycogenosis type II and neuronal ceroid lipofuscinoses: comparison of data in different populations

\begin{tabular}{|c|c|c|c|c|c|c|c|}
\hline \multirow[t]{2}{*}{ Disease } & \multicolumn{4}{|l|}{ Czech Republic } & \multicolumn{3}{|c|}{ Other countries } \\
\hline & $\begin{array}{l}\text { No. of patients } \\
1975-2008^{\mathrm{a}}\end{array}$ & $\begin{array}{l}\text { Prevalence } \\
\text { per } 100,000^{\mathrm{b}}\end{array}$ & $\begin{array}{l}\text { Poisson } 95 \% \\
\text { confidence interval }\end{array}$ & $\begin{array}{l}\text { Carrier } \\
\text { frequency }{ }^{\mathrm{c}} \times 10^{3}\end{array}$ & $\begin{array}{l}\mathrm{NL} \\
\text { Prevalenc }\end{array}$ & $\begin{array}{l}\text { Portugal } \\
\text { ee per } 100,000\end{array}$ & $\begin{array}{l}\text { Australia } \\
0 \text { live births }\end{array}$ \\
\hline$\alpha$-Mannosidosis & 4 & 0.38 & $0.10-0.98$ & 3.92 & 0.09 & 0.12 & 0.1 \\
\hline$\beta$-Mannosidosis & 2 & 0.16 & $0.02-0.59$ & 2.56 & 0.13 & 0.12 & 0 \\
\hline ISSD & 1 & 0.02 & $0.0-0.13$ & 0.97 & 0.07 & 0 & 0.19 \\
\hline Fucosidosis & 0 & & & & 0.05 & 0 & 0 \\
\hline Aspartylglucosaminuria & 0 & & & & 0.13 & 1.72 & 0.05 \\
\hline$\alpha$-N-acetyl-galactosaminidase def. & 0 & & & & 0.2 & 0 & 0 \\
\hline Galactosialidosis & 0 & & & & 0.04 & 0.77 & 0 \\
\hline Mucolipidosis I & 3 & 0.07 & $0.01-0.20$ & 1.66 & 0.05 & 0 & 0.02 \\
\hline Mucolipidosis II/III & 3 & 0.22 & $0.05-0.65$ & 2.98 & 0.24 & 0.81 & 0.31 \\
\hline Mucolipidosis IV & 1 & 0.02 & $0.0-0.13$ & 0.97 & & & \\
\hline Glycogenosis type II (all) & 12 & 0.37 & $0.13-0.81$ & 3.86 & 2 & 0.17 & 0.69 \\
\hline NCL 1 & 2 & 0.19 & $0.02-0.70$ & 2.79 & & 0.17 & \\
\hline NCL 2 & 28 & 0.36 & $0.24-0.52$ & 3.79 & & 0.07 & \\
\hline NCL 3 & 2 & 0.27 & $0.03-0.96$ & 3.27 & & 0.48 & \\
\hline NCL 4 & 1 & 0.02 & $0.0-0.13$ & 0.97 & & & \\
\hline NCL 5 & 2 & 0.21 & $0.03-0.77$ & 2.92 & & & \\
\hline NCL 6 & 1 & 0.02 & $0.0-0.13$ & 0.97 & & 1.43 & \\
\hline NCL 7 & 18 & 0.85 & $0.49-1.36$ & 5.81 & & & \\
\hline NCL unspecified ${ }^{d}$ & 20 & 0.37 & $0.22-0.58$ & & & & \\
\hline NCL (all types) & 74 & 2.29 & $1.03-5.15$ & & & 2.14 & \\
\hline
\end{tabular}

$N L$ Netherlands, ISSD infantile sialic acid storage disease, $N C L$ neuronal ceroid lipofuscinosis

${ }^{\mathrm{a}}$ Total number of patients diagnosed between 1975 and 2008

${ }^{\mathrm{b}}$ Data for prevalence calculations are in Table 6

${ }^{\mathrm{c}}$ Carrier per 1 live birth

${ }^{\mathrm{d}}$ Unspecified NCL were diagnosed on the basis of histochemical and ultrastructural examination of biopsy samples combined with the evaluation of clinical data. No material was available for enzyme and DNA analysis

births. Data on patients with lipidoses, mucopolysaccharidoses, and other LSDs detected during the study period, including carrier frequencies in the Czech population, are summarized in Tables 1, 2 and 3, respectively. Detailed data on the birth prevalence of specific disorders and their subtypes can be found in Tables 4, 5 and 6 .

To date, no individuals in the Czech population have been conclusively diagnosed with Farber disease, Schindler disease, Danon disease, Sanfilippo D disease, galactosialidosis, fucosidosis, aspartylglucosaminuria, or prosaposin, saposins, or GM2 activator protein deficiencies.

\section{Discussion}

The overall prevalence of LSDs in the Czech population (12.25 per 100,000), which represents a typical Central European population, is comparable to prevalences reported for Australia (12.9 per 100,000), the Netherlands (14 per
$100,000)$ and Italy $(12.1$ per 100,000) (Meikle et al. 1999; Poorthuis et al. 1999; Dionisi-Vici et al. 2002). The higher prevalence of LSDs reported for the northern Portuguese population (25 per 100,000) might reflect the relative geographic isolation and more extensive studying of that particular population of this region (Pinto et al. 2004). The most frequent single LSD is Gaucher disease in the Czech Republic, Italy and Australia, GM2 gangliosidosis in Portugal, and Pompe disease in the Netherlands.

In the Czech population, lipidoses were most frequently diagnosed (5.0 per 100,000 live births), followed by MPS (3.72) and NCL (2.29). In addition to the LSD diagnoses in Czech patients, 96 cases from Slovakia were confirmed at our Institute during the studied period; $41 \%$ with lipidoses, $39 \%$ with MPS, and 20\% with GSD II or NCLs. These Slovakian patients have not been included in our prevalence calculations as former Czechoslovakia was divided into two independent states, the Czech Republic and the Slovak Republic, in 1993. Interestingly, the four cases of prosaposin 
Table 4 Lipidoses: data for calculation of birth prevalence

\begin{tabular}{|c|c|c|c|c|c|c|c|}
\hline Disease & $\begin{array}{l}\text { No. of patients } \\
1975-2008^{\mathrm{a}, \mathrm{b}}\end{array}$ & $\begin{array}{l}\text { Years } \\
\text { of birth }\end{array}$ & $\begin{array}{l}\text { No. of } \\
\text { live births }\end{array}$ & $\begin{array}{l}\text { No. of } \\
\text { patients }^{\mathrm{c}}\end{array}$ & $\begin{array}{l}\text { Prevalence ( } 1 \text { per } \\
\text { numbers of live births) }\end{array}$ & $\begin{array}{l}\text { Prevalence } \\
\text { per } 100,000\end{array}$ & $\begin{array}{l}\text { Carrier } \\
\text { frequency }\end{array}$ \\
\hline Gaucher type I, early & $12(10)$ & 1974-1996 & 3090902 & 12 & 257575 & 0.39 & 254 \\
\hline Gaucher type I, late & $29(28)$ & $1945-1980$ & 5956028 & 24 & 248168 & 0.40 & 249 \\
\hline Gaucher type II and III ${ }^{\mathrm{e}}$ & $8(8)$ & 1980-1998 & 2352492 & 8 & 294062 & 0.34 & 271 \\
\hline Gaucher (all types) & 49 & & & 44 & 88397 & 1.13 & 149 \\
\hline Niemann-Pick A & $10(8)$ & 1963-2002 & 5480885 & 10 & 548089 & 0.18 & 370 \\
\hline Niemann-Pick B $+\operatorname{atyp}^{f}$ & $13(11)$ & 1948-1996 & 7362146 & 11 & 669286 & 0.15 & 409 \\
\hline Niemann-Pick A/B & 23 & & & 21 & 301327 & 0.33 & 274 \\
\hline Niemann-Pick $C^{\mathrm{g}}$ & $54(45)$ & $1965-2003$ & 5271310 & 48 & 109819 & 0.91 & 166 \\
\hline Fabry $^{\mathrm{h}}$ & $49(24)$ & $\begin{array}{l}\text { 1945-2002 } \\
\text { Male }\end{array}$ & $\begin{array}{lll}8 & 518 & 601 \\
4 & 382 & 068\end{array}$ & $\begin{array}{l}44 \\
44\end{array}$ & $\begin{array}{l}193605 \\
99592\end{array}$ & $\begin{array}{l}0.52 \\
1.00^{\mathrm{n}}\end{array}$ & 96803 \\
\hline Fabry female & $78(24)$ & 1945-2005 & 8812161 & 68 & 129591 & 0.77 & \\
\hline $\mathrm{Krabbe}^{\mathrm{i}}$ & $15(15)$ & $1977-2002$ & 3249150 & 13 & 249935 & 0.40 & 250 \\
\hline MLD infantile & $13(11)$ & 1970-1999 & 4195564 & 13 & 322736 & 0.31 & 284 \\
\hline Juvenile & $5(4)$ & 1970-2004 & 4661324 & 5 & 932265 & 0.11 & 483 \\
\hline Adult & $7(7)$ & 1968-1980 & 2188004 & 6 & 364667 & 0.27 & 302 \\
\hline MLD (all types) & 25 & & & 24 & 144647 & 0.69 & 190 \\
\hline CESD, Wolman ${ }^{\mathrm{j}}$ & $18(15)$ & $1963-2002$ & 5480885 & 15 & 365392 & 0.27 & 302 \\
\hline GM1 gangliosidosis & $13(13)$ & 1970-2003 & 4563660 & 12 & 380305 & 0.26 & 308 \\
\hline GM2 Tay-Sachs ${ }^{\mathrm{k}}$ & $10(10)$ & 1971-1992 & 3362889 & 10 & 336289 & 0.30 & 290 \\
\hline GM2 Sandhoff & $3(3)$ & 1992-2007 & 1594949 & 3 & 531650 & 0.19 & 365 \\
\hline Lipidoses all types & $259^{1} / 337^{\mathrm{m}}$ & & & $234^{1} / 302^{\mathrm{m}}$ & 20000 & $5.0^{1 / 5.77^{\mathrm{m}}}$ & $71^{\circ}$ \\
\hline
\end{tabular}

$M L D$ Metachromatic leukodystrophy, CESD cholesteryl ester storage disease

${ }^{a}$ Total number of patients diagnosed between 1975 and 2008

${ }^{\mathrm{b}}$ Number of families with particular disorder in parentheses

${ }^{\mathrm{c}}$ Number of patients taken for the calculation of birth prevalence. To avoid underestimation, some patients were not included into the prevalence calculation (e.g., patients born before 1945 were excluded). For prevalence definition, see "Patients and Methods"

${ }^{\mathrm{d}}$ Expressed as 1 carrier per number of shown live births

${ }^{\mathrm{e}}$ One stillborn case

${ }^{\mathrm{f}} \mathrm{NP}$ type B in 6 slowly progressive visceral cases and atypical protracted neurovisceral phenotype in 7 cases [Pavlů-Pereira H, et al. J Inherit Metab Dis 2005;28:203-227]

${ }^{\mathrm{g}}$ Including one case of NP type C2 [Elleder M. et al. Virchows Arch 2001;439:206-211]

${ }^{\mathrm{h}}$ Classical phenotype in 43 male patients and cardiac variant in 6 male patients (two families) [Elleder M, et al. Cas Lek Cesk 1990;129:368-372]

${ }^{\mathrm{i}}$ Infantile form in 12 patients, late infantile in 2 patients, and adult form in one patient [Kostalova E, et al. Ceska Slov Neurol Neurochir 2006; 69/102:200-210]

${ }^{\mathrm{j}}$ One infantile patient (Wolman disease) and 17 juvenile and adult cases [Elleder M, et al. Cas Lek Cesk 1999;138:719-724]

${ }^{\mathrm{k}}$ Including two adult patients

${ }^{1}$ Fabry females not included

${ }^{\mathrm{m}}$ Fabry females included

${ }^{\mathrm{n}}$ Male live births

${ }^{\circ}$ Carrier frequency of lipidoses except for Fabry disease

deficiency so far diagnosed at our Institute came from neighboring populations (Slovak, German) (Hulkova et al. 2001; Elleder et al. 2005; Kuchar et al. 2009).

The birth prevalence of the most frequent LSD in the Czech Republic, Gaucher disease, is 1.13 per 100,000 live births, followed by Niemann-Pick C (0.91), MPS III (0.91), MPS IV (0.73), and MPS I (0.72). Comparison of these prevalences to those in selected foreign populations (Tables 1,2 and 3) is complicated by the differences in methods used for calculation. When we compared the calculations of prevalence in the Czech population based on the method of Poorthuis et al. (1999) used in this study (see "Patients and Methods") to the method reported by Meikle et al. (1999) (the prevalence calculated as the number of 
Table 5 Mucopolysaccharidoses: data for calculation of birth prevalence

\begin{tabular}{|c|c|c|c|c|c|c|c|}
\hline Disease & $\begin{array}{l}\text { No. of patients } \\
1975-2008^{\mathrm{a}, \mathrm{b}}\end{array}$ & $\begin{array}{l}\text { Years } \\
\text { of birth }\end{array}$ & $\begin{array}{l}\text { No. of } \\
\text { live births }\end{array}$ & $\begin{array}{l}\text { No. of } \\
\text { patients }\end{array}$ & $\begin{array}{l}\text { Prevalence (1 per } \\
\text { number of live births) }\end{array}$ & $\begin{array}{l}\text { Prevalence } \\
\text { per } 100,000\end{array}$ & $\begin{array}{l}\text { Carrier } \\
\text { frequency }\end{array}$ \\
\hline MPS I & $20^{\mathrm{e}}(17)$ & 1984-2008 & $2,772,559$ & 20 & 138,628 & 0.72 & 186 \\
\hline MPS II & $22(19)$ & $\begin{array}{l}\text { 1969-2005 } \\
\text { Male }\end{array}$ & $\begin{array}{l}4,906,700 \\
2,520,373\end{array}$ & $\begin{array}{l}21 \\
21\end{array}$ & $\begin{array}{l}233,652 \\
120,018\end{array}$ & $\begin{array}{l}0.43 \\
0.83^{\mathrm{f}}\end{array}$ & 116,826 \\
\hline MPS III A & $18(14)$ & 1977-2006 & $3,648,541$ & 17 & 214,620 & 0.47 & 232 \\
\hline MPS III B & 1 & 1975-2008 & $4,261,897$ & 1 & $4,261,897$ & 0.02 & 1,032 \\
\hline MPS III C & $5(4)$ & 1984-1992 & $1,179,745$ & 5 & 235,949 & 0.42 & 243 \\
\hline MPS III (all types) & 24 & & & 23 & 109,502 & 0.91 & 165 \\
\hline MPS IV A & $14(9)$ & $1987-2003$ & $1,826,473$ & 13 & 140,498 & 0.71 & 187 \\
\hline MPS IV B & 1 & 1975-2008 & $4,261,897$ & 1 & $4,261,897$ & 0.02 & 1,032 \\
\hline MPS IV $(A+B)$ & 15 & & & 14 & 136,986 & 0.73 & 185 \\
\hline MPS VI & $2(2)$ & 1968-1995 & $4,115,057$ & 2 & $2,057,529$ & 0.05 & 717 \\
\hline MPS VII & 1 & 1975-2008 & $4,261,897$ & 1 & $4,261,897$ & 0.02 & 1,032 \\
\hline MPS I-VII & 84 & & & 81 & 34,909 & 2.86 & 93 \\
\hline MPS-unspecified & $32(27)$ & 1960-1989 & $4,533,496$ & 27 & 167,907 & 0.60 & 205 \\
\hline MSD & $3(1)$ & $1962-1969$ & $1,144,467$ & 3 & 381,489 & 0.26 & 309 \\
\hline MPS all types & 119 & & & 111 & 26,865 & 3.72 & $82^{\mathrm{g}}$ \\
\hline
\end{tabular}

MPS mucopolysaccharidosis, MSD multiple sulphatase deficiency

${ }^{\text {a }}$ Total number of patients diagnosed between 1975 and 2008

${ }^{\mathrm{b}}$ Number of families with particular disorder in parentheses

${ }^{\mathrm{c}}$ Number of patients taken for the calculation of birth prevalence. To avoid underestimation, some patients were not included into the prevalence calculation (e.g., patients born before 1945 were excluded). For prevalence definition, see "Patients and Methods"

${ }^{\mathrm{d}}$ Expressed as 1 carrier per number of shown live births

${ }^{\mathrm{e}}$ Hurler syndrom in 16 patients, Hurler/Scheie in 2 patients and Scheie syndrom in 2 patients

${ }^{\mathrm{f}}$ Male live births

${ }^{\mathrm{g}}$ Carrier frequency of MPS excluding MPS II

patients divided by the total number of live births during the study period), the calculations resulted in underestimation or overestimations of some individual disorders. This is the case for disorders with delayed onset (e.g., frequencies of Fabry disease were 0.52 and 1.14 per 100,000 , and frequencies of cholesterol ester storage disease were 0.27 and 0.42 , if calculated using the methods of Poorthuis et al. (1999) and Meikle et al. (1999), respectively). Also, unavailability of some diagnostic methods during the study period (some methods were introduced as late as the 1990s) may explain some discrepancies found in our calculations using the two methods. Although prevalence values for some disorders calculated using either of the methods were within the confidence intervals (data not shown), for other disorders prevalence values fell outside this interval (e.g., the frequencies differed for MPS III C $(0.42$ and 0.11 per $100,000)$, MPS IVA (0.71 and 0.32), NCL 2 (0.36 and 0.65$)$ and NCL 7 (0.85 and 0.42), if calculated according to the methods used by Poorthuis et al. (1999) and Meikle et al. (1999), respectively).

Thus, establishment of standard rules for calculation of birth prevalence-a defined term in clinical epidemiology-is highly recommended. This would enable more reliable comparison of data from different populations. Based on our experience, the calculation of the ratio of the number of patients to the number of live births during the patients' births period (Poorthuis et al. 1999) fits well to the definition of prevalence. Underestimation of the birth prevalence may result from lack of recognition of early clinical signs and symptoms or phenotypic diversity, including adult forms of the disease (e.g., Fabry disease, adult Krabbe disease, adult MLD, cholesteryl ester storage disease, and adult GSD II). Thus, the calculated birth prevalence is probably the lowest estimate as the diagnosis is commonly delayed for years. Screening studies have shown that certain groups of patients, for example individuals with renal failure on haemodialysis, may harbor missed Fabry patients (Nakao et al. 2003; Kotanko et al. 2004). The nationwide screening study among 3,370 chronic haemodialysis patients in the Czech Republic disclosed four previously unrecognized Fabry males and one female from five unrelated families. Subsequent family screening ascertained Fabry disease in another 12 individuals, including 8 females (Merta et al. 2007). Patients with unexplained cardiomyopathy represent 
Table 6 Glycoproteinoses, mucolipidoses, glycogenosis type II and neuronal ceroidlipofuscinoses: data for calculation of birth prevalence

\begin{tabular}{|c|c|c|c|c|c|c|c|}
\hline Disease & $\begin{array}{l}\text { No. of patients } \\
1975-2008^{\mathrm{a}, \mathrm{b}}\end{array}$ & $\begin{array}{l}\text { Years } \\
\text { of birth }\end{array}$ & $\begin{array}{l}\text { No. of } \\
\text { live births }\end{array}$ & $\begin{array}{l}\text { No. of } \\
\text { patients }^{\mathrm{c}}\end{array}$ & $\begin{array}{l}\text { Prevalence ( } 1 \text { per } \\
\text { numbers of live births) }\end{array}$ & $\begin{array}{l}\text { Prevalence } \\
\text { per } 100,000\end{array}$ & $\begin{array}{l}\text { Carrier } \\
\text { frequency }\end{array}$ \\
\hline$\alpha$-Mannosidosis & $4(3)$ & 1985-1992 & $1,042,804$ & 4 & 260,701 & 0.38 & 255 \\
\hline$\beta$-Mannosidosis & $2(1)$ & $1950-1956$ & $1,223,386$ & 2 & 611,693 & 0.16 & 391 \\
\hline ISSD & 1 & 1975-2008 & $4,261,897$ & 1 & $4,261,897$ & 0.02 & 1,032 \\
\hline Mucolipidosis I & $3^{\mathrm{e}}(2)$ & 1969-1999 & $4,338,729$ & 3 & $1,446,243$ & 0.07 & 601 \\
\hline Mucolipidosis II/III & $3(3)$ & 1994-2007 & $1,352,219$ & 3 & 450,740 & 0.22 & 336 \\
\hline Mucolipidosis IV & $1^{\mathrm{f}}$ & 1975-2008 & $4,261,897$ & 1 & $4,261,897$ & 0.02 & 1,032 \\
\hline GP + ML (all types) & 14 & & & 14 & 112,995 & 0.87 & 170 \\
\hline Glycogenosis type II infantile & $6(5)$ & 1979-1999 & $2,614,075$ & 6 & 435,679 & 0.23 & 330 \\
\hline Glycogenosis type II juvenile & $6(5)$ & 1972-2002 & $4,167,930$ & 6 & 694,655 & 0.14 & 417 \\
\hline Glycogenosis type II (all) & 12 & & & 12 & 267,750 & 0.37 & 259 \\
\hline NCL 1 & $2(2)$ & $1970-1975$ & $1,033,447$ & 2 & 516,724 & 0.19 & 359 \\
\hline NCL 2 & $28(25)$ & 1949-2003 & $7,803,068$ & 28 & 278,681 & 0.36 & 264 \\
\hline NCL 3 & $2(2)$ & $1979-1983$ & 749,520 & 2 & 374,760 & 0.27 & 306 \\
\hline NCL 4 & 1 & $1975-2008$ & $4,261,897$ & 1 & $4,261,897$ & 0.02 & 1,032 \\
\hline NCL 5 & $2(1)$ & 1983-1989 & 935,553 & 2 & 467,777 & 0.21 & 342 \\
\hline NCL 6 & 1 & 1975-2008 & $4,261,897$ & 1 & $4,261,897$ & 0.02 & 1,032 \\
\hline NCL 7 & $18(16)$ & 1985-2002 & $2,002,025$ & 17 & 117,766 & 0.85 & 172 \\
\hline NCL-unspecified & $20(17)$ & 1965-1999 & $4,903,214$ & 18 & 272,401 & 0.37 & 261 \\
\hline NCL (all types) & 74 & & & 71 & 43,551 & 2.29 & 104 \\
\hline
\end{tabular}

ISSD infantile sialic acid storage disease, $G P$ glycoproteinosis, $M L$ mucolipidosis, $N C L$ neuronal ceroid lipofuscinosis

${ }^{\mathrm{a}}$ Total number of patients diagnosed between 1975 and 2008

${ }^{\mathrm{b}}$ Number of families with particular disorder in parentheses

${ }^{\mathrm{c}}$ Number of patients taken for the calculation of birth prevalence. To avoid underestimation, some patients were not included into the prevalence calculation (e.g. patients born before 1945 were excluded). For prevalence definition see "Patients and Methods"

${ }^{\mathrm{d}}$ Expressed as 1 carrier per number of shown live births

${ }^{\mathrm{e}}$ One infantile patient and two juvenile siblings with cherry-red spot myoclonus syndrome [Ledvinova J, et al. J Inherit Metab Dis 1994;17:118-119]

${ }^{\mathrm{f}}$ Atypical case of ML IV with ocular restricted phenotype [Dobrovolny R, et al. Am J Ophthalmol 2007; 143:663-671]

another group at risk of having Fabry disease where screening is justified (Monserrat et al. 2007). Such LSD screening initiatives for selected LSDs will contribute to the identification of the true prevalence of these disorders (Spada et al. 2006; Chien et al. 2008).

Fabry heterozygotes have not been included in the calculation of birth prevalence in previous reports (Meikle et al. 1999; Poorthuis et al. 1999; Pinto et al. 2004). However, they commonly develop clinical symptoms and severe complications, generally a few years later, as in affected men (Deegan et al. 2006; Wilcox et al. 2008). When we included Fabry heterozygotes in the calculations, the prevalence of Fabry disease increased by 2.5 times to 1.29 per 100,000 live births, that of lipidoses from 5.0 to 5.77 per 100,000 and the overall prevalence of LSDs reached 13.02 per 100,000 (Table 4). Therefore, we propose that Fabry heterozygotes ought to be included in the calculation of the birth prevalence of Fabry disease.

Reliable calculation of the birth prevalence is dependant on a correctly defined pathogenic cause underlying the condition. Recent molecular studies have provided evidence for at least ten separate genetic loci (CLN1-CLN10) for NCL (Peltonen et al. 2000; Siintola et al. 2007). These new findings necessitated reclassification of our 37 cases that had formerly been provisionally classified as NCL6 into NCL5, NCL6, and NCL7 subgroups. The latter turned out to be of high prevalence in the Roma Gypsy population (Kousi et al. 2009). About a quarter of the NCL cases remain unspecified due to the lack of material suitable for mutation analysis.

Athough specific LSDs are generally reckoned to be rare disorders, as a group of inherited metabolic disorders they are quite common, as seen from published and our data. The information on birth prevalencies of LSDs is available from countries with a long tradition of diagnosis of LSDs; however, for most populations, these date are missing. Epidemiological data on these disorders are important in genetic counselling for calculation of the risk for the disorders in the other members of affected families and subsequently for the public health care systems. 
Importantly, awareness of the clinical aspects of these life-threatening and progressively disabling genetic diseases among the medical community should increase, allowing earlier diagnosis. In turn, this will offer an opportunity for early therapeutic intervention. Dependant on the diagnosed disorder, such intervention may include enzyme replacement therapy, bone marrow transplantation, or other current or future therapies. Last but not least, it should be borne in mind that genetic counselling and prenatal diagnosis in families affected by a genetic metabolic disorder still form the basic strategy for lowering the number of patients with these severe disorders.

Acknowledgements We were able to present this laboratory-based survey thanks to the close collaboration with colleagues, clinicians, biochemists and technicians from the Institute of Inherited Metabolic Disorders. The authors wish to thank all clinicians from hospitals in the Czech Republic for referring patients' material; their diagnostic skills made this data collection possible. We are also indebted to foreign laboratories that kindly performed confirmatory analysis in selected cases and to Dr. Hans Ebels (Genzyme Corporation) for his editorial support. This study was supported by grant projects MSM0021620806 of the Ministry of Education and Youth, and MZOVFN2005 of the Ministry of Health of the Czech Republic.

Open Access This article is distributed under the terms of the Creative Commons Attribution Noncommercial License which permits any noncommercial use, distribution, and reproduction in any medium, provided the original author(s) and source are credited.

\section{References}

Applegarth DA, Toone JR, Lowry RB (2000) Incidence of inborn errors of metabolism in British Columbia, 1969-1996. Pediatrics 105(1): 10

Baehner F, Schmiedeskamp C, Krummenauer F et al (2005) Cumulative incidence rates of the mucopolysaccharidoses in Germany. J Inherit Metab Dis 28(6):1011-1017

Balreira A, Gaspar P, Caiola D et al (2008) A nonsense mutation in the LIMP-2 gene associated with progressive myoclonic epilepsy and nephrotic syndrome. Hum Mol Genet 17 (14):2238-2243

Berkovic SF, Dibbens LM, Oshlack A et al (2008) Array-based gene discovery with three unrelated subjects shows SCARB2/LIMP-2 deficiency causes myoclonus epilepsy and glomerulosclerosis. Am J Hum Genet 82(3):673-684

Claussen M, Heim P, Knispel J, Goebel HH, Kohlschutter A (1992) Incidence of neuronal ceroid-lipofuscinoses in West Germany: variation of a method for studying autosomal recessive disorders. Am J Med Genet 42(4):536-538

De Duve C, Pressman BC, Gianetto R, Wattiaux R, Appelmans F (1955) Tissue fractionation studies. 6. Intracellular distribution patterns of enzymes in rat-liver tissue. Biochem J 60(4):604617

Deegan PB, Baehner AF, Barba Romero MA, Hughes DA, Kampmann C, Beck M (2006) Natural history of Fabry disease in females in the Fabry Outcome Survey. J Med Genet 43(4):347-352

Dionisi-Vici C, Rizzo C, Burlina AB et al (2002) Inborn errors of metabolism in the Italian pediatric population: a national retrospective survey. J Pediatr 140(3):321-327
Dobrovolny R, Dvorakova L, Ledvinova J et al (2005) Relationship between $\mathrm{X}$-inactivation and clinical involvement in Fabry heterozygotes. Eleven novel mutations in the alpha-galactosidase A gene in the Czech and Slovak population. J Mol Med 83(8):647654

Elleder M, Jerabkova M, Befekadu A et al (2005) Prosaposin deficiency-a rarely diagnosed, rapidly progressing, neonatal neurovisceral lipid storage disease. Report of a further patient. Neuropediatrics 36(3):171-180

Gibas AL, Klatt R, Johnson J, Clarke JT, Katz J (2008) Disease rarity, carrier status, and gender: a triple disadvantage for women with Fabry disease. J Genet Couns 17(6):528-537

Heim P, Claussen M, Hoffmann B et al (1997) Leukodystrophy incidence in Germany. Am J Med Genet 71(4):475-478

Hulkova H, Cervenkova M, Ledvinova J et al (2001) A novel mutation in the coding region of the prosaposin gene leads to a complete deficiency of prosaposin and saposins, and is associated with a complex sphingolipidosis dominated by lactosylceramide accumulation. Hum Mol Genet 10(9):927-940

Chien YH, Chiang SC, Zhang XK et al (2008) Early detection of Pompe disease by newborn screening is feasible: results from the Taiwan screening program. Pediatrics 122(1):e39-45

Jalanko A, Braulke T (2009) Neuronal ceroid lipofuscinoses. Biochim Biophys Acta 1793(4):697-709

Kotanko P, Kramar R, Devrnja D et al (2004) Results of a nationwide screening for Anderson-Fabry disease among dialysis patients. J Am Soc Nephrol 15(5):1323-1329

Kousi M, Siintola E, Dvorakova L et al (2009) Mutations in CLN7/ MFSD8 are a common cause of variant late-infantile neuronal ceroid lipofuscinosis. Brain 132(Pt 3):810-819

Kuchar L, Ledvinova J, Hrebicek M et al (2009) Prosaposin deficiency and saposin B deficiency (activator-deficient metachromatic leukodystrophy): report on two patients detected by analysis of urinary sphingolipids and carrying novel PSAP gene mutations. Am J Med Genet A 149A (4):613-621

Malm G, Lund AM, Mansson JE, Heiberg A (2008) Mucopolysaccharidoses in the Scandinavian countries: incidence and prevalence. Acta Paediatr 97(11):1577-1581

Meikle PJ, Hopwood JJ, Clague AE, Carey WF (1999) Prevalence of lysosomal storage disorders. JAMA 281(3):249-254

Merta M, Reiterova J, Ledvinova J et al (2007) A nationwide blood spot screening study for Fabry disease in the Czech Republic haemodialysis patient population. Nephrol Dial Transplant 22 (1):179-186

Monserrat L, Gimeno-Blanes JR, Marin F et al (2007) Prevalence of Fabry disease in a cohort of 508 unrelated patients with hypertrophic cardiomyopathy. J Am Coll Cardiol 50(25):23992403

Moore D, Connock MJ, Wraith E, Lavery C (2008) The prevalence of and survival in Mucopolysaccharidosis I: Hurler, Hurler-Scheie and Scheie syndromes in the UK. Orphanet J Rare Dis 3:24

Nakao S, Kodama C, Takenaka T et al (2003) Fabry disease: detection of undiagnosed hemodialysis patients and identification of a "renal variant" phenotype. Kidney Int 64(3):801-807

Nelson J, Crowhurst J, Carey B, Greed L (2003) Incidence of the mucopolysaccharidoses in Western Australia. Am J Med Genet A 123(3):310-313

Ozkara HA, Topcu M (2004) Sphingolipidoses in Turkey. Brain Dev 26(6):363-366

Peltonen L, Savukoski M, Vesa J (2000) Genetics of the neuronal ceroid lipofuscinoses. Curr Opin Genet Dev 10(3):299-305

Pinto R, Caseiro C, Lemos M et al (2004) Prevalence of lysosomal storage diseases in Portugal. Eur J Hum Genet 12(2):87-92 
Poorthuis BJ, Wevers RA, Kleijer WJ et al (1999) The frequency of lysosomal storage diseases in The Netherlands. Hum Genet 105 $(1-2): 151-156$

Saftig P (2005) Lysosomes. Landes Bioscience/Eurekah.com, Georgetown, Texas

Scriver CR, Beaudet AL, Sly WS, Valle D (2001) The metabolic and molecular bases of inherited disease. McGraw-Hill, New York

Siintola E, Topcu M, Aula N et al (2007) The novel neuronal ceroid lipofuscinosis gene MFSD8 encodes a putative lysosomal transporter. Am J Hum Genet 81(1):136-146

Spada M, Pagliardini S, Yasuda M et al (2006) High incidence of later-onset Fabry disease revealed by newborn screening. Am J Hum Genet 79(1):31-40
Staretz-Chacham O, Lang TC, LaMarca ME, Krasnewich D, Sidransky E (2009) Lysosomal storage disorders in the newborn. Pediatrics 123(4):1191-1207

Strachan T, Read AP (2004) Human molecular genetics. Garland, New York

Uitenbroek DG (1997) Binomial. SISA. <http://www.quantitativeskills. $\mathrm{com} / \mathrm{sisa} /$ distributions/binomial.htm>. Accessed $20041 \mathrm{Jan}$.

Wang RY, Lelis A, Mirocha J, Wilcox WR (2007) Heterozygous Fabry women are not just carriers, but have a significant burden of disease and impaired quality of life. Genet Med 9(1):34-45

Wilcox WR, Oliveira JP, Hopkin RJ et al (2008) Females with Fabry disease frequently have major organ involvement: lessons from the Fabry Registry. Mol Genet Metab 93(2):112-128 